\title{
Designing mobile farmer application using object oriented analysis and design
}

\author{
Abdul Mufti a, Desi Novianti b, Dewi Anjani c \\ $a, b, c$ Informatics Engineering, Universitas Indraprasta PGRI, Jakarta, Indonesia
}

email:aabdul.mufti@gmail.com,bdesi.novi4nti@gmail.com,cdewiunindra@gmail.com

\begin{tabular}{l}
\hline A R T I C L E I N F O \\
\hline Article history: \\
Received 9 February 2018 \\
Revised 28 May 2018 \\
Accepted 29 May 2018 \\
Avaible online 2 June 2018 \\
\hline Kata kunci: \\
Android \\
mobile \\
e-Farmers \\
pertanian \\
\hline Keywords: \\
agriculture \\
Android \\
mobile \\
e-Farmers \\
\hline Style APA dalam mensitasi \\
artikel ini: \\
Mufti, A., Novianti, D., \& \\
Anjani, D. (2017). Designing \\
mobile farmer application \\
using object oriented \\
analysis and design. Register: \\
Jurnal Ilmiah Teknologi Sistem \\
Informasi, 3(2), 105-113. \\
\end{tabular}

\begin{abstract}
A B S TR A K
Sistem e-farmers merupakan sebuah sistem penjualan berbasis teknologi (e-commerce) yang dapat diakses melalui website, digunakan untuk membantu para petani menjual hasil pertanian berupa beras secara langsung ke konsumen. Namun dengan adanya kendala dalam hal kepemilikan perangkat komputer dan laptop, petani maupun konsumen yang merupakan pengakses website ladangku.id beralih menggunakan perangkat mobile. Dengan alasan ini, maka peneliti membuat sebuah sistem e-farmers yang awalnya berupa website dapat juga diakses melalui perangkat mobile dengan sistem operasi Android. Karena sistem berbasis website berbeda dengan sistem berbasis mobile, untuk itu dibutuhkan sebuah perancangan sistem e-farmer yang berbasis mobile yang akan terintegrasi dengan sistem berbasis website. Di mana metode yang digunakan adalah metode Research and Development (RED), yang mana mengembangkan sistem yang sudah ada dan hasil akhirnya menghasilkan sebuah produk berupa rancangan sistem aplikasi e-farmers yang dapat berkerja di platform Android.
\end{abstract}

\section{A B S T R A C T}

E-farmers system is a technology-based commerce system (e-commerce) that can be accessed via a website, used for assisting farmers in selling rice product directly to consumers. However, due to the constraint in the ownership of computer and laptop, farmers and consumers as the users of the website ladangku.id now use mobile devices instead. For this reason, the researcher developed an e-farmers system that was initially only accessible via the website but now can be accessed via mobile devices with the Android operating system. Because the website-based system and mobile-based system are different, it is necessary to have a mobilebased e-farmer system design that is integrated with the website-based system. The method used was Research and Development (R\&D) method by developing the existing system, and the final product was in the form of a design of e-farmer application system that can work on Android platform.

(c) 2017 Register: Jurnal Ilmiah Teknologi Sistem Informasi. All rights reserved.

\section{Introduction}

E-farmers is an Electronic Commerce (e-commerce) specifically designed for selling rice product online. E-farmers was developed due to the fact that the marketing channels for rice product from farmers to consumers are still traditional, disabling the consumers to buy rice directly from the farmers. This has caused the rise of prices offered because the consumers buy through middlemen. Farmers will only gain small profits in the indirect sales to the consumers to prevent middlemen, also known as the third party, from selling at an excessively expensive price to the consumers.

Currently, website-based e-farmers can be accessed optimally using a Personal Computer (PC) or Laptop. However, in reality, e-farmers is more commonly accessed using mobile devices or smartphones because the number of farmers and consumers owning these devices overbears those owning PC and laptops. The access to e-farmers using the smartphone is less optimal. The small smartphone screen makes it difficult for the users to use the system. On the basis of this reason, a design 
of e-farmers for mobile devices or smartphones that is integrated with the website-based e-farmers system has developed. This will allow for optimal use of e-farmers, either via the website or via smartphones.

\section{State of the Art}

Previous research related to theory by the author, including:

1) Xiaohui et al. (2014) trans-regional distributed E-Commerce architecture aims at solving the urgent problems such as resource recomposition and distributed deployment ahead of large commerce systems. Based on it, we propose the global scheme that could be built in the agentbased P2P network or another environment, and the latest software technologies could be used in the servers to publish the cooperation services. As far as the present technology is concerned, Web service P2P and agent technology are a good choice, which are the three key supporting technologies of the architecture. Each branch market can be operated and maintained independently regardless of the existence of others, but their order services are to be centrally processed by the order server.

2) Tarazonaet al. (2014) an article is a proposal based on the paradigm of Model Driven Architecture (MDA), describes a metamodel Ecommerce that supports the development of a web application. This application ensures semantic interoperability, which is achieved with the definition of Ontology and technical interoperability, which is achieved with the migration of data from the applicative to other e-commerce platforms. This is possible thanks to a generator that access to repositories of information and facilitates the migration of data from the ecommerce website to other platforms. In this way reduce the complexity and minimizing the efforts for the creation and maintenance of e-commerce solutions

3) Mufti et al. ( 2017) this research is aimed at designing an e-commerce system to buy and sell rice crops, which in turn will help rice farmers to facilitate the sale and purchase of rice from farmers directly without any can be done. With the term 'middleman'. With the design of ecommerce system of agricultural products that this rice then the conventional sales system can be directly applied so that consumers can directly buy rice without longer.

4) Anjani et al. (2017) this study was aimed at creating a system and an appropriate technology that can help farmers market their agricultural products to consumers to make it easier and have the advantage that will improve the welfare of the farmers. For consumers, they obtained the desired agricultural products in accordance with the quality and price. For the government, it can organize the needs of farmers and the public more quickly. It is expected that this appropriate technology can reduce the purchase channels of agricultural products from the farmers to the consumers. All purchasing activities of the consumers, i.e. the choice of agricultural products in accordance with the price, quality, quantity, shipping channels and types of transaction can be more quickly and easily to do with e-farmers. And for sales activities, i.e. capital in carrying out from the planting plan until the crops, seeding, fertilization and the amount of the successful crops can be directly reported to the farmers to be known by the consumers and the government.

\section{Research method}

Research and development method is a research method used for producing a certain product and to test the effectiveness of the product. To produce a certain product, research using need analysis (using survey method or qualitative method) is needed, and to test the effectiveness of the product for the product to be functional in the general public, research for testing the effectiveness of the product (using experimental method) should be conducted (Sugiyono, 2008).

The basic research method is usually used in the need analysis research to produce hypothetical products. To test the hypothetical product, experimental or action research is used. After being tested, the product can be applied. The product testing process using experiment is called applied research. Research and development aim to invent, develop and validate a product (Gall, Gall, \& Borg, 2007). The 10 stages of model development in the Research and Development (R\&D) methods are as follows (Gall, 
Gall, \& Borg, 2007). This research is included into applied research, where the stages can be seen in the following Fig. 1:

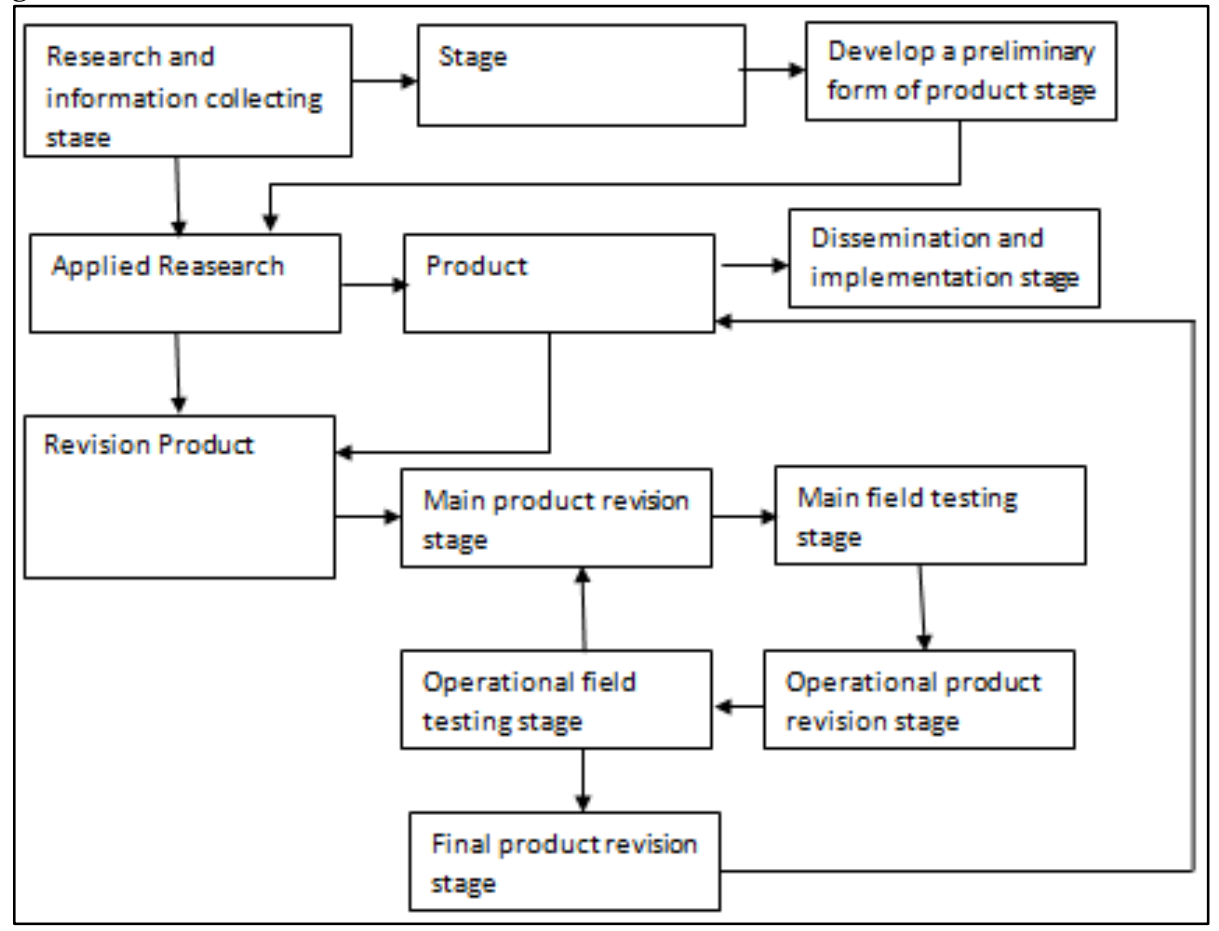

Fig. 1. The steps of applied methods in $\mathrm{R} \& \mathrm{D}$ research

1) Research and information collecting stage, including the study of literature related to the problem, studied, measurement of need, small-scale research, and preparation for formulating the research framework;

2) Stage, including the development of research plan that covers the formulation of skill and expertise related to the problem, the determination of the objective to be achieved in every stage, the research design or steps and if possible/necessary, the conduct of limited feasibility study;

3) Develop a preliminary form of product stage, in which the preliminary form of the product is developed. Included in this step are the preparation of supporting components, the preparation of guideline and manual and the evaluation of the applicability of supporting tools.

4) Preliminary field testing stage, in which a preliminary field tryout is conducted on a limited scale, which involves 1 to 3 partners and 6-12 subjects. In this stage, the data collection and analysis can be conducted using interview, observation or questionnaire;

5) Main product revision stage, in which the preliminary product produced is revised based on the result of the preliminary tryout. It is highly possible that the revision is conducted more than once in accordance with the results shown in the limited tryout in order to obtain the main product draft (model) that is ready to be tried out on a larger scale.

6) Main field testing stage, commonly called the main tryout, that involves the larger audience, including 5 to 15 partners and 30 to 100 subjects.

7) Operational product revision stage, in which a revision/improvement of the tryout result on a larger scale is conducted. Therefore, the product developed is already in the form of an operational model that is ready to be validated;

8) Operational field testing stage, in which the operational model produced is validated. This is conducted on 10 to 30 partners and 40 to 200 subjects using questionnaires, interview and observation, and the results are analyzed. The purpose of this stage is to determine whether the model developed is truly ready to be used at location without the need for direction or assistance of the researcher/model developer;

9) Final product revision stage, in which the final revision is carried out on the model developed in order to produce the final product; 
10)Dissemination and implementation stage, which is a stage of disseminating the product/model developed to the general public. The main step in this phase is communicating and socializing the invention/model, either in the form of a seminar of the research results, publication through the journal, or exposure to the stakeholders relevant to the research results.

R\&D is an important means of achieving future growth and maintaining a relevant product in the market. A United State of America government agency, the National Science Foundation defines three types of R\&D:

1) Basic Research, when research aims to understand a subject matter more completely and build on the body of knowledge relating to it, then it falls in the basic research category. This research does not have much practical or commercial application. The findings of such research may often be of potential interest to a company

2) Applied Research has more specific and directed objectives. This type of research aims to determine methods to address a specific customer/industry need or requirement. These investigations are all focused on specific commercial objectives regarding products or processes.

3) Development is when findings of a research are utilized for the production of specific products including materials, systems, and methods. Design and development of prototypes and processes are also part of this area. A vital differentiation at this point is between development and engineering or manufacturing. Development is research that generates requisite knowledge and designs for production and converts these into prototypes. Engineering is the utilization of these plans and research to produce commercial products.

\section{Result}

From the results of data collection based on interviews and observations to the field then obtained the user requirement, can be seen Table 1 .

Table 1. User requierment

\begin{tabular}{|c|c|c|}
\hline User & Process & Data and Information \\
\hline Farmer & $\begin{array}{ll}- & \text { Entering registration data } \\
- & \text { Incorporate planting capital } \\
- & \text { Include products to be sold } \\
\text { - } & \text { Check purchases and make sales } \\
\text { - } & \text { Check the results of purchases } \\
& \text { every semester or every year }\end{array}$ & $\begin{array}{ll}\text { - } & \text { Data and information of farmers } \\
\text { - } & \text { Data and information on capital and crops } \\
\text { - } & \text { Product information sold } \\
\text { - } & \text { Information on the benefits of each } \\
& \text { semester and or annually }\end{array}$ \\
\hline
\end{tabular}

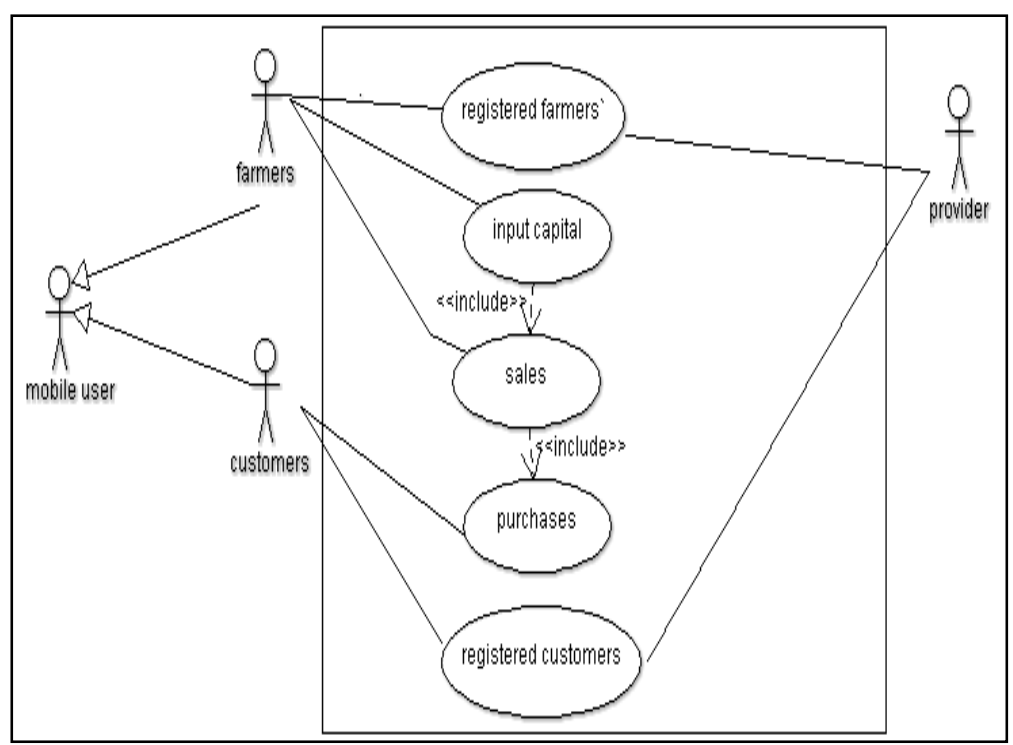

Fig. 2. Top level use case diagram

In this research, the analysis of the system design used object-oriented methodology by using UML diagrams. The initial concept of the system development is conducting the need analysis, in which the needs and expectations of users are ensured in order that the application meets the demand, requirement, and satisfaction of the users. Therefore, in the UML context, a use case diagram is created 
to describe how the software is used by the users. The use case diagram of this system can be seen in Fig. 2.

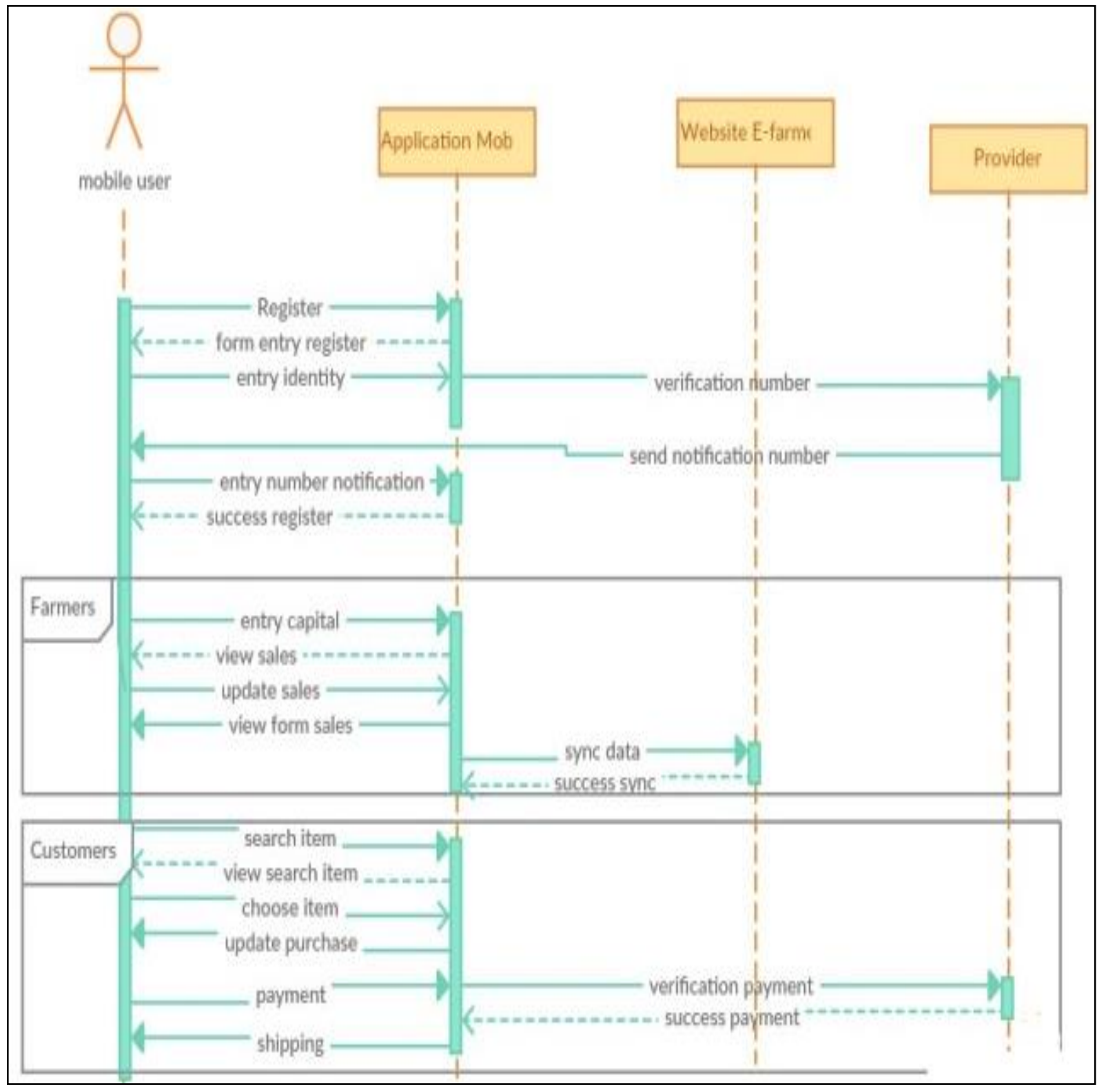

Fig. 3. Sequence diagram system E-Farmers mobile

The need specification is useful for determining the users and actors involved to create a use case diagram. The users and actors involved are as follows:

a) Farmers

For farmers, the behaviors exhibited when interacting with the application are as follows:

1) The farmer installs the e-farmers application dedicated to farmers via smartphone

2) The farmer registers him-/herself as a farmer

3) The farmer inputs his/her phone number for registration

4) The farmer inputs the registration notification number sent to the phone number registered

5) The farmer successfully completes the registration

6) The farmer inputs the data related to agriculture

7) The farmer views the result of the data input

8) The farmer uploads the right data

9) The farmer views the data of the agricultural products to be sold

b) Consumers

For consumers, the behaviors exhibited when interacting with the application are as follows: 
1) The consumer installs the e-farmers application dedicated to consumers via smartphone

2) The consumer views the data of the agricultural product sales

3) The consumer registers him-/herself as a consumer

4) The consumer inputs the data required as a consumer

5) The consumer purchases products

6) The consumer selects the payment method

7) The consumer makes payment

8) The consumer receives notification of the payment and the estimation of product acceptance via email

9) The consumer inputs the information notifying that he/she has successfully received the products.

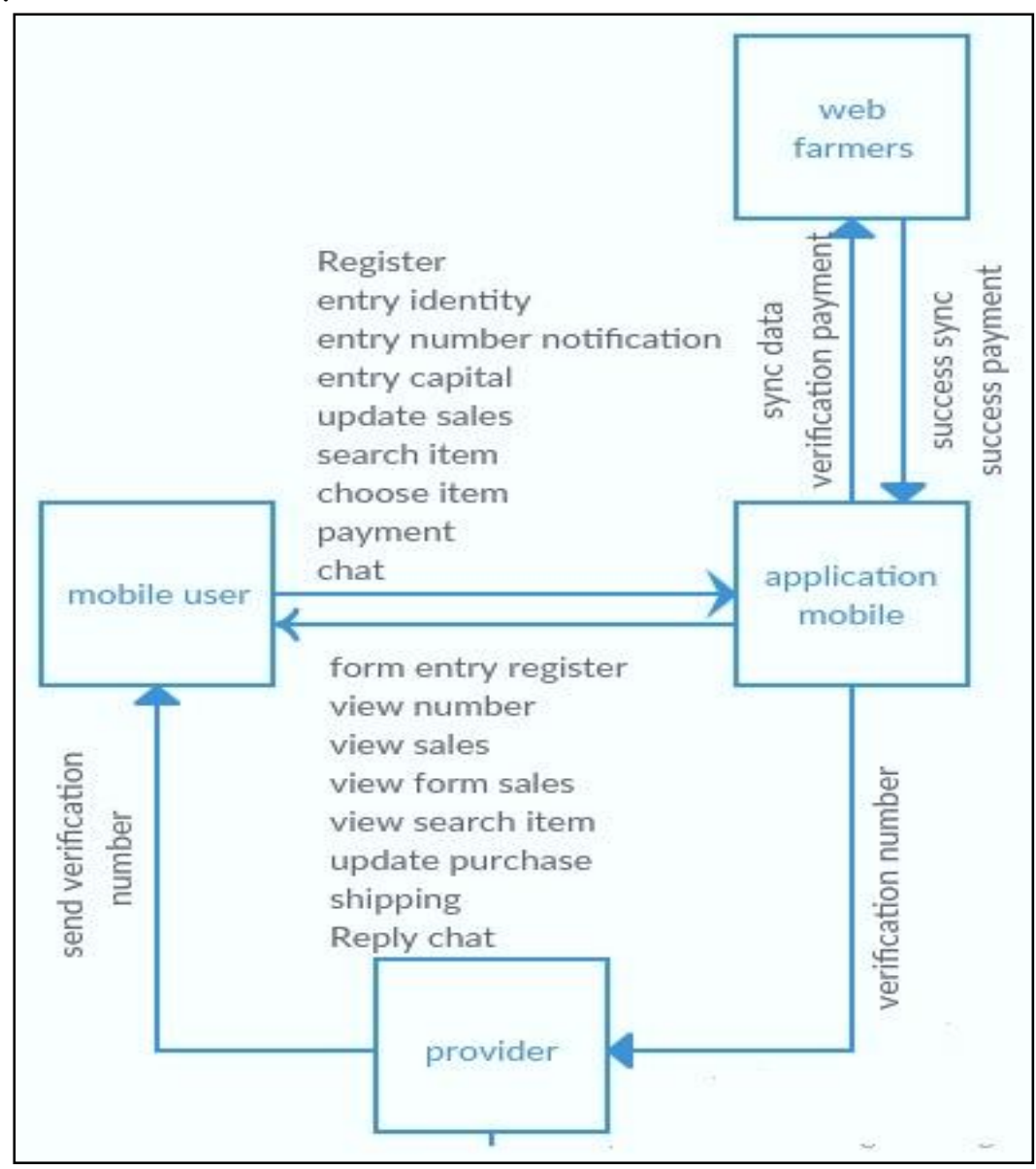

Fig. 4. Collaboration diagram system E-Farmers mobile

The next step is determining the Class for describing the object of the attribute, property and the general relationship between object and semantic. The Class in this system is comprised of farmers, consumers, e-farmer of farmers and e-farmer of customers.

After the class is formed, the next step is developing the sequence diagram Fig. 3, which will be useful for showing the series of messages sent between objects as well as the interaction between objects formed at a certain point during the system execution. The sequence diagram also describes the interaction between a number of objects in sequence. Collaboration diagram Fig. 4 is a picture of the system scenario that shows the interaction of the objects that is set by the surrounding objects and the relationship between one object and another.

Activity diagram Fig. 5 and Fig. 6 is a picture that describes the flow of the activities used for describing the activities formed in an operation to allow for the use of other activities. After the design, then the next process is a trial application to farmers. At the time of the first trial, farmers interested in this application, but when registering and logging in need of email, a problem where farmers do not have email, so farmers become pessimistic with this application. With this problem then the app is 
revised, where the login and all the complaints of the customer and the farmer using only the registered cell phone number.

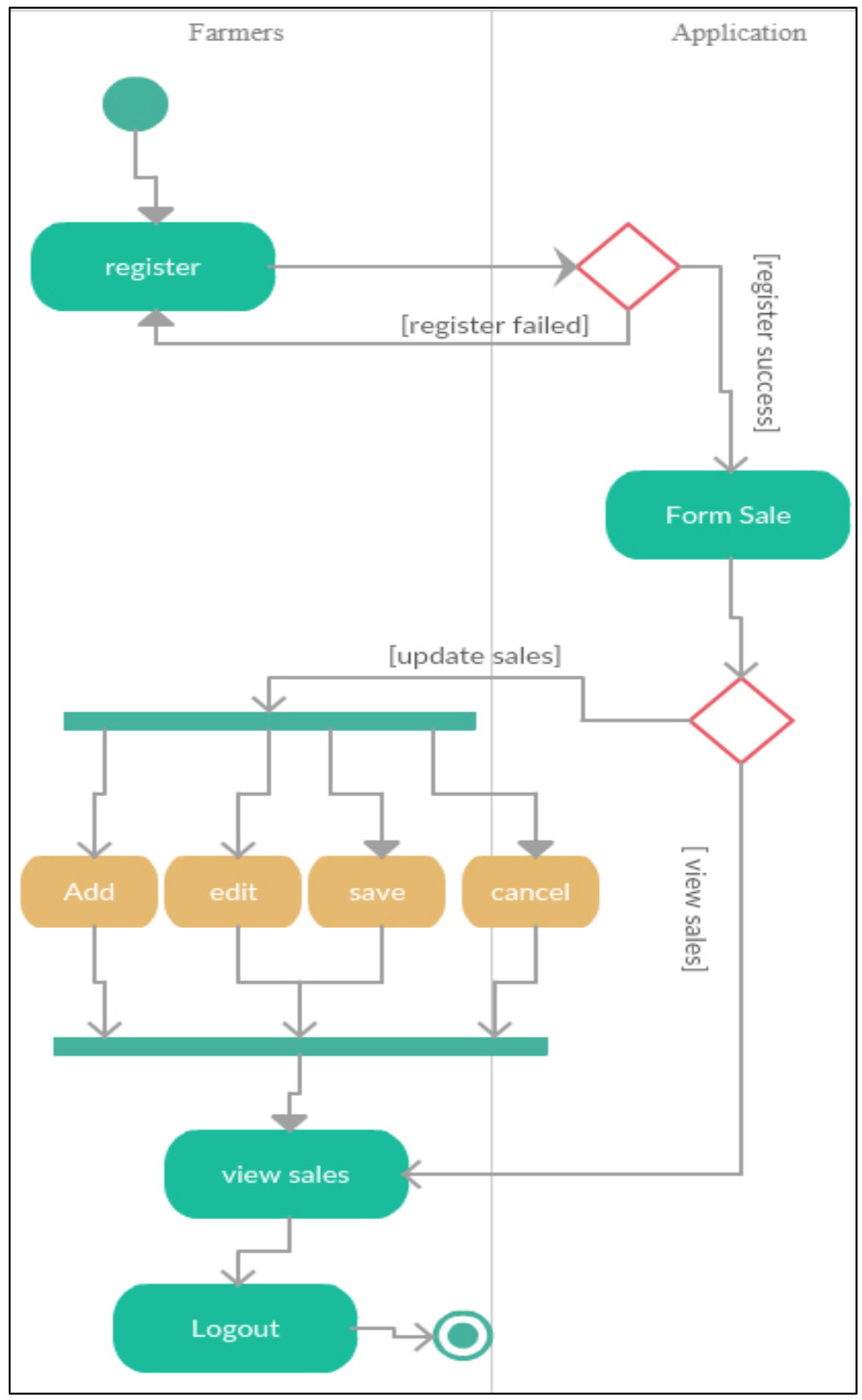

Fig. 5. Activity diagram system E- Farmers mobile for farmers

The creation of e-farmer systems in the form of mobile applications can provide convenience to farmers and consumers to use the e-farmers system, by simply utilizing smartphones. However, a system that has been implemented is said to be successful will be affected by many complex constraints, namely compatible information, systems and business processes are not synchronized (Murtadho \& Wahid, 2016).

Likewise with this system, there are several factors that will be a failure if not quickly addressed mainly related to user farmers, where farmers who use this application is still categorized weak in terms of technology. If there is no continuous training then the possibility of failure will be enormous. 


\section{Conclusion}

The e-farmer system is a technology-based sales system (e-commerce) that can be accessed through the website, used to help farmers sell farm produce together. In practice, however, many access the e-farmer system using a smartphone, whereby using usability and user acceptance tests, 70\% of farmers use smartphones to access the system. Of the 21 users, users who use the smartphone amounted to 15 people and the rest using a PC. Thus, a mobile e-farmer system based on the Android operating system was created. In making this research that will produce a product then using $\mathrm{R} \& \mathrm{D}$ method where the process of testing the product with the experiment is called applied research. The design of mobile applications uses UML, which facilitates object-based application design. Expected by the design of this design, the application is made to be optimal, this application can be accessed both with smartphones and websites. So it makes it easier for farmers and consumers to make buying and selling of rice.

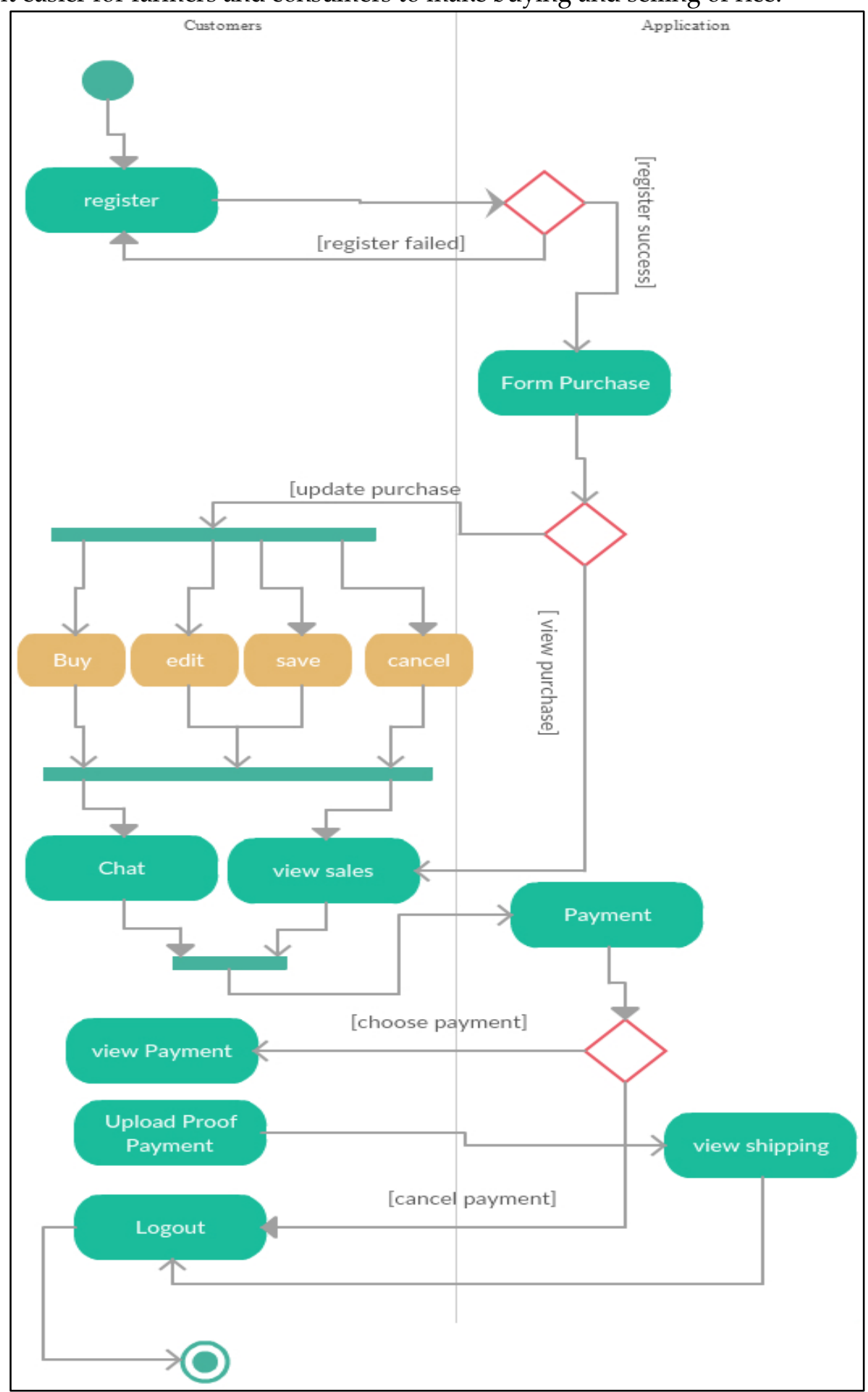

Fig. 6. Activity diagram system E- Farmers mobile for customers 


\section{Acknowlegment}

Appreciation and gratitude to Direktorat Riset dan Pengabdian Masyarakat, Dirjen Penguatan Riset dan Pengembangan, Kementerian Riset, Teknologi dan Pendidikan Tinggi, who has financed Produk terapan research in 2017 under the title "Pemodelan E-Petani Dalam Meningkatkan Produktivitas dan Kesejahteraan Petani di Desa Sukaraja, Kecamatan Tambelang, Kabupaten Bekasi, Provinsi Jawa Barat, Indonesia".

\section{Referensi}

Anjani, D., Novianti, D., \& Mufti, A. (2017). E-Farmers Modeling in Increasing Productivity and Welfare of the farmers in sukaraja village, Tembelang Subdistrict, Bekasi Regency, Indonesia. UG Economics Faculty International Conference 2017 (pp. 405-412). Jakarta: Gunadarma University.

Gall, M. D., Gall, J. P., \& Borg, W. R. (2007). Educational Research: An Introduction (8th ed.). Georgia: Pearson.

Mufti, A., Novianti, D., \& Anjani, D. (2017). Analisis perancangan sistem e-commerce untuk jual beli hasil pertanian berupa beras. Seminar Nasional Teknologi Informasi dan Multimedia 2017 (pp. 2.3-13 2.3-18). Yogyakarta: STMIK AMIKOM Yogyakarta.

Murtadho, M. A., \& Wahid, F. (2016). Permasalahan Implementasi Sistem Informasi Di Perguruan Tinggi Swasta. Register: Jurnal Ilmiah Teknologi Sistem Informasi, 2(1), 17-21.

Sugiyono. (2009). Metode Penelitian Pendidikan Pendekatan Kuantitatif, Kualitatif, dan $R$ \& D. Bandung: Alfabeta.

Tarazona, G. M., Pelayo, B. C., Sanjuán, O., \& Rodríguez, L. A. (2014). e-Commerce Metamodel Based on MDA. IEEE Latin America Transactions, 12(4), 699-705.

Xiaohui, G., Rong, G., JianYu, W., \& Chongning, H. (2014). Key Technology of Distributed E-commerce System Architecture. Indonesian Journal of Electrical Engineering and Computer Science, 12(5), 39873993. 